\title{
KEBIJAKAN KAWASAN TANPA ROKOK TERHADAP PENGGUNA VAPE (ROKOK ELEKTRIK) DI KABUPATEN BADUNG
}

\section{Gusti Ngurah Surya Adhi Kencana Putra}

Magister Ilmu Hukum Fakultas Hukum Universitas Udayana

E-mail: ngurahsurya@live.com

\begin{abstract}
Abstrak
Perlindungan kesehatan masyarakat untuk memperoleh lingkungan sehat adalah bagian melindungi hak asasi manusia. Wujud perlindungan tersebut dengan membuat kebijakan Kawasan Tanpa Rokok. akan tetapi terjadi perdebatan terkait penerapannya pada pengguna vape (rokok elektrik). Tujuan dari kajian penelitian artikel ini untuk memecahkan permasalahan terkait penggunaan vape (rokok elektrik) pada Kawasan Tanpa Rokok di kabupaten Badung. Penulisan artikel ilmiah ini dikaji dengan metode normatif dan pendekatan konseptual serta pendekatan perundang-undangan. Kajian ini menemukan vape (rokok elektrik) secara konsep sama dengan rokok dalam Peraturan Dearah Kabupaten Badung Nomor 10 Tahun 2017. Secara normatif kewenangan Pemerintah Kabupaten Badung terhadap vape (rokok elektrik) sama dengan rokok konvensional.
\end{abstract}

Kata kunci: kesehatan; kawasan tanpa rokok; rokok elekrik.

\begin{abstract}
Protection of public health to get a healthy environment is a part of the human rights protection. The form of protection is by making a Non Smoking Area policy. But there is a debate related to its application to vape users (ecigarettes). The purpose of this article research study is problems solve related to use of vape (e-cigarette) in the Non Smoking Area Badung regency. The writing of this scientific article uses a normative method with a conceptual and legislation approach. This study found that vape (e-cigarette) is conceptually the same with cigarette in Badung Regional Regulation Number 10 Year 2017. Normatively, the Badung Regency Government's authority over vape (electric cigarette) is the same as conventional cigarette
\end{abstract}

Keywords: health; no smoking area; e-cigarettes. 


\section{Pendahuluan}

Indonesia sebagai sebuah negara yang masih berkembang pada saat ini masih berjuang untuk mewujudkan kesejahteraan bagi masyarakatnya. Mewujudkan sebuah kesejahteraan bagi masyarakat merupakan cita - cita pendiri bangsa Indonesia. Atas dasar hal itulah Pemerintah Indonesia berusaha menciptakan agar masyarakatnya dapat menikmati kehidupan sejahtera. Tolak ukur dari sebuah kesejahteraan suatu bangsa adalah peningkatan taraf hidup serta peningkatan kesehatan di masyarakat maupun individu suatu bangsa. Semakin sehat masyarakat maupun individu suatu bangsa beserta generasi penerusnya semakin baik pula kesejahteraan suatu bangsa itu. Kesehatan menjadi hal serius untuk dikerjakan oleh pemerintah dan menjadi salah satu program prioritas pembangunan yang tengah dilaksanakan oleh Pemerintah. Tanpa bangsa yang sehat kemajuan dan kesejahteraan Negara Kesatuan Republik Indonesia sangat susah untuk di wujudkan. Maka pembangunan bidang kesehatan sangat penting menjadi prioritas dari arah kebijakan yang di ambil oleh negara dalam menjalakan kekuasaannya.

Pada zaman globalisasi serta zaman modern seperti pada saat ini, kebijakan pemerintah di bidang kesehatan menjadi prioritas. Prioritas kebijakan pada bidang kesehatan sejalan dengan pandangan serta pemahaman masyarakat terhadap kesehatan dirinya semakin meningkat. Pembangunan terhadap kesehatan masyarakat menjadi salah satu prioritas dalam kehidupan bermasyarakat dan bernegara, maka masyarakat sangat menyadari pentingnya pembangunan dalam bidang kesehatan masyarakat. Kesehatan masyarakat merupakan unsur penting dalam mencapai suatu kesejahteraan, karena kesehatan merupakan salah satu unsur dasar dalam mencapai sebuah kesejahteraan di masyarakat. ${ }^{1}$

Perwujudan perlindungan kesehatan masyarakat merupakan wujud perjuangan untuk mencapai cita - cita pembangunan dan kemerdekaan bangsa Indonesia yang tersiratkan pada makna teks pembukaan konstitusi Indonesia yang menjadi satu kesatuan dokumen dengan Undang - Undang Dasar Negara Republik Indonesia (pada penulisan setelah ini di singkat menjadi UUD Indonesia 1945). Perlindungan terhadap kesehatan bangsa dan rakyat Indonesia menjadi peran vital pemerintah dalam setiap tindakan maupun kebijakan - kebijakan yang ditetapkan. Perlindungan kesehatan masyarakat oleh pemerintah merupakan wujud terhadap melindungi hak - hak fundamental yang disiratkan tafsiran hak asasi masyarakat yang wajib di

${ }^{1}$ Prabhata, I. G. A. N. I. “Meningkatkan Pariwisata Bali melalui Kepastian Penegakan Hukum Atas Pelanggaran Kawasan tanpa Rokok dalam Peraturan Daerah Propinsi Bali Nomor 10 Tahun 2011". Jurnal Magister Hukum Udayana (Udayana Master Law Journal), 4(1). (2015). hlm. 58. 
proteksi oleh pemerintah Indonesia selaku pemengang kekuasaan. Ketentuan terhadap perlindungan kesehatan masyarakat termaktub pada ketentuan "Pasal 28H ayat (1) UUD Indonesia 1945". Pada ketentuan tersebut menetukan bahwa masyarakat layak untuk mendapatkan haknya berupa lingkungan yang bersih dan sehat. Tujuan dari ketentuan tersebut diharapkan menciptakan sebuah kesejahteraan lahir, jamani maupun rohaninya.

Kesehatan masyarakat pada dasarnya sebuah hak asasi bagi individu dan warga masyarakat serta kewajiban pemerintah negara memproteksi serta memberikan lindungan atas hal tersebut untuk melaksanakan kewajibannya yang dimuat dalam pengaturan Hak Asasi Manusia. Perlindungan hak - hak manusia secara fundamental pada bidang kesehatan masyarakat secara Internasional juga ditentukan dalam Pasal 25 pada Deklarasi Universal terhadap Hak Asasi Manusia. Ketentuan yang termaktub di Pasal 25 dalam pengaturan Deklarasi Universal terhadap Hak Asasi menegaskan secara eksplisit bahwasannya pemerintah wajib menjamin kesehatan masyarakat. Pengaturan atas hal tersebut memiliki makna bahwa melindungi serta menjamin masyarakat yang sehat merupakan perwujudan dari proteksi hak hak yang menjadi bagian hak asasi masyarakat. ${ }^{2}$

Wujud dalam melindungi hak - hak fundamental yang dimiliki Manusia pada bidang kesehatan salah satu bentuk kongkret dengan menciptakan lingkungan yang bebas dari polusi dan bebas dari ancaman bahaya penyakit. Kebijakan untuk menciptakan lingkungan serta area yang terhindar dari polusi dan bebas dari ancaman resiko penyakit bagi masyarakat sangat penting, hal tersebut dengan menciptakan sebuah area bersih dari polusi maupun polutan udara serta dimaknai sebagai area sehat bagi masyarat maka dapat menghindari masyarakat dari berbagai ancaman penyakit akibat dari lingkungan yang kotor serta berpolusi dan area masyarakat yang kurang sehat. Wujud kebijakan pemerintah untuk menciptakan lingkungan yang sehat salah satunya adalah menerapkan kebijakan kawasan yang dilarang untuk melakukan aktivitas merokok.

Kawasan yang merupakan area tanpa adanya rokok diharapkan untuk melindungi masyarakat dari bahaya atas paparan yang terdapat pada asap rokok yang di keluarkan oleh aktivitas merokok. Kebijakan Kawasan Tanpa Rokok diharapkan mampu memproteksi masyarakat yang tidak melakukan aktivitas menghisap rokok untuk tidak turut serta menerima akibat dari orang yang merokok. Pada kenyataan bahaya dari kegiatan merokok lebih besar diterima oleh masyarakat di sekitar perokok. Istilah atas masyarakat yang

${ }^{2}$ Shirley, K. F. L., \& Siarif, T. J. “Kebijakan Tentang Pedoman Kawasan Tanpa Rokok Dikaitkan Dengan Asas Manfaat”. SOEPRA, 2(1), 104-111. (2016). 
tidak melakukan kegiatan menhisap rokok namun masih ada di lingkungan orang yang melakukan aktivitas merokok adalah perokok pasif dan istilah untuk masyarakat yang melakukan kegiatan merokok disebut perokok aktif. Pada kegiatan merokok, seorang perokok aktif hanya menerima sekitar $25 \%$ zat berbahaya dari asap rokok, sedangkan 75\% zat berbahaya dari rokok beredar pada udara sekitar lingkungan perokok tersebut. 75\% zat berbahaya dari kegiatan merokok sangat mungkin masuk ke tubuh orang - orang sekitarnya dalam hal ini adalah perokok pasif. Akibat dari hal tersebut masyarakat sebagai perokok yang tidak aktif dalam hal ini bertindak pasif merokok dapat menerima berbagai hal buruk terkait dampak kesehatan baik dalam kurun waktu singkat maupun kurun waktu yang akan datang. Dampak jangka pendek seorang perokok pasif yang terpapar pulutan asap rokok mengakibatkan mata merah, sesak nafas, bersin ataupun batuk - batuk. Dampak perokok pasif jangka panjang jika terus menerus terkena polutan dari asap rokok dapat menyebabkan asma, sesak nafas, kanker bahkan serangan jantung. Bagi ibu hamil bahaya dari aktivitas orang yang merokok di sekitarnya dapat menimbulkan gangguan terhadap kemahilannya serta kesehatan janinnya serta dapat menyebabkan keguguran. ${ }^{3}$ Dari berbagai dampak negatif yang di timbulkan oleh aktivitas merokok maka penting pemerintah menerapkan kebijakan Kawasan Tanpa Rokok untuk menanggulangi dan mencegah berbagai akibat yang tidak postitif dari kegiatan Menghisap rokok yang dilakukan oleh perokok aktif.

Penerapan dari pengaturan area terlarang untuk rokok beserta aktivitasnya merupakan wujud untuk menciptakan lingkungan bebas dari polutan rokok dan sehat bagi masyarakat. Wujud memberikan lingkungan yang sehat merupakan cara memberikan lindungan terhadap hak kesehatan secara hakiki bagi perokok pasif. Peran Pemerintah untuk melindungi Hak Asasi perokok pasif sangat penting. Kebijakan tersebut sejalan dengan esensi Indonesia sebagai negara hukum. Perlindungan perokok yang tidak aktif dalam hal ini perokok yang pasif merupakan bagian penjabaran unsur negara hukum yakni hak asasi manusia yang dilindungi negara.

Proteksi dalam melindungi hak - hak yang menjadi suatu fundamental suatu hak asasi yang dimiliki oleh masyarakat sebagai manusia adalah bagian penting dari suatu pemerintahan penyelenggaraan negara berdasarkan atas hukum dalam segala kebijakan. Dasar Indonesia dikatakan sebagai sebuah negara hukum di atur dalam ketentuan konstitusi Republik Indonesia. Hal tersebut tercermin dalam Pasal 1 pada ayat ketiga dalam konstitusi UUD Indonesia 1945. Sebagai sebuah penyelenggaran pemerintahan negara yang

\begin{tabular}{ccccc}
\hline 3 & Alodokter. Bahaya Menjadi Perokok & Pasif. Available from \\
https://www.alodokter.com/bahaya-menjadi-perokok-pasif. (Diakses 10 Oktober 2019)
\end{tabular}


berbasis atas hukum dan kedaulatannya, maka penelenggraan Negara Kesatuan Republik Indonesia dalam setiap kebijakan maupun praktek ketatatanegaraan yang dilakukakannya harus di dasarkan atas dasar hukum yakni peraturan yang masih berlaku dalam hirarki perundang - undangan negara. ${ }^{4}$

Kebijakan publik pemerintah dalam penetapannya wajib melindungi hak - hak yang menjadi kodrat asasi sebagai manusia karena secara harafiah bagian dalam karakteristik khas sebuah negara yang pemerintahnya ditentukan secara hukum. Dalam melindungi terhadap hak - hak yang menjadi kodrat manusia, kebijakan perlindungan tersebut harus di dasarkan atas aturan yang diatur ke dalam perundang - undangan negara Indonesia beserta elemen unsur hukum konstitusi dalam mendasari kewenangan pemerintah. Kebijakan pemerintah dalam landasannya mendasari atas peraturan yang merupakan bagian herarki perundang - undangan di Indonesia memiliki maksa bahwasannya setiap penyelenggaraan negara di dasarkan atas dasar asas legalitas. Dalam menjalankan asas legalitas tersebut, sistem konstitusi juga memberikan hak atau kewenangan dasar untuk melaksanakannya. Kebijakan perlindungan Hak Asasi Manusia yang didasarkan oleh asal legalitas dan konstitus sejalan dengan Indonesia sebagai sebuah negara hukum berdasarkan atas ciri khas tersebut. ${ }^{5}$

Sejalan dengan Indonesia sebagai sebuah negara hukum, maka perlindungan Hak Asasi perokok pasif untuk mendapatkan lingkungan yang sehat harus di dasarkan atas aturan dalam peraturan sesuai tingkatan herarki perundang -undangan dalam ketatanegaraan Indonesia. Upaya dalam rangka memberikan lindungan serta melindungi tersebut maka pemerintah membuat kebijakan Kawasan Tanpa Rokok. Kebijakan kawasan atau area tersebut diatur berdasarkan pada Pasal 115 dalam pengaturan ayat pertama pada "Undang Undang Republik Indonesia Nomor 36 Tahun 2009 Tentang Kesehatan" (pada penulisan berikutnya di singkat dengan UU Indonesia Tentang Kesehatan). Secara yuridis ketentuan UU Indonesia Tentang Kesehatan yang menentukan segala hal berkaitan dengan kesehatan mengatur kawasan - kawasan untuk dilarang kegiatan merokok. Area ataupun lingkungan kawasan - kawasan tersebut ditunjukan lebih kepada kawasan yang merupakan kawasan tempat beraktifitas dan bersosialisasinya masyarakat. Tempat yang dimaksud dalam UU Indonesia Tentang Kesehatan diantaranya area pada fasilitas utama dan

\footnotetext{
${ }^{4}$ Agus Salim Andi Gadjong, Pemerintah Daerah Kajian Politik dan Hukum, Ghalia Indonesia, Bogor, 2007, hlm. 33

${ }^{5}$ Aswandi, B., \& Roisah, K. "Negara Hukum Dan Demokrasi Pancasila Dalam Kaitannya Dengan Hak Asasi Manusia (Ham)". Jurnal Pembangunan Hukum Indonesia, 1(1), (2019). 128145.
} 
penunjang sarana kesehatan masyarakat, kawasan pada fasilitas kegiatan pendidikan dan pengajaran, kawasan kegiatan peribadahan serta keagamanan, kawasan yang merupakan bagian dari sarana dan prasarana tranportasi publik serta kawasan lainnya seperti taman bermain, taman kota, maupun kawasan yang menjadi bagian dari pelayanan publik. Secara sederhana Kawasan Tanpa Rokok yang dimaksudkan oleh UU Indonesia Tentang Kesehatan adalah kawasan atau area cakupan dari bagian sebagai sarana fasilitas publik maupun sarana fasilitas sosial. Kawasan tersebut di tentukan sebagai kawasan yang tidak diperbolehkan merokok dimaksudkan agar masyarakat yang tidak merokok dapat terhindar dari dampak negatif atas aktifitas masyarakat yang merokok serta paparan asap rokok yang diakibatkan dari kegiatan tersebut.

Dalam menjalankan kebijakan serta aturan lingkungan bebas dari aktivitas rokok tersebut negara perlu dukungan dari pemerintah daerah untuk mengefektivitaskan pelaksanaakan aturan kebijakan publik terkait area larangan melakukan aktivitas merokok di wilayah domain kekuasaannya untuk menjadi kewenangan pemerintah daerah tersebut. Penerapan mengefektivitaskan kebijakan itu sejalan pada pelaksanaan otonomi daerah yang dianut pada sistem tata pemerintahan Indonesia. Dasar memberikan kewenangan tersebut diatur dalam Pasal 115 pada ketentuan ayat ke dua di UU Indonesia Tentang Kesehatan. Ketentuan dalam Pasal 115 pada ketentuan ayat ke dua di UU Indonesia Tentang Kesehatan memerintahkan untuk seluruh pemerintah provinsi hingga pemerintah di kabupaten dan kota di semua wilayah dalam lingkup Indonesia membuat serta menetapkan kebijakan terhadap area yang bebas dari berbagai hal yang berkaitan dengan rokok. Berdasarkan landasan dari aturan tersebut, pemerintah melimpahkan kewenangannya kepada pemerintahan kabupaten dan pemerintahan kota dalam mengatur area bebas dari aktivitas merokok tersebut untuk memberikan landasakan dengan peraturan daerah.

Tekmaktub pada aturan Pasal ke 115 di bagian ayat kedua UU Indonesia Tentang Kesehatan memberikan legitimasi kepada pemerintahan di provinsi hingga pemerintahan di kabupaten serta kota untuk menjalakan otonominya dalam menerapkan lingkungan serta area bebas dari polutan rokok di daerah kewenangannya. Dalam konteks kawasan Tanpa Rokok pemerintah mendelegasikan kewenangannya kepada pemerintah daerah untuk mengatur terkait kebijakan lingkungan yang menjadi sebuah kawasan larangan merokok. Konsep bahwasannya kebijakan Kawasan Tanpa Rokok bagian dari kewenangan yang diberikan secara delegasi di dasarkan berdasarkan norma hukum yang mengatur dalam Pasal ke 115 di bagian ayat kedua UU Indonesia Tentang Kesehatan. Kewenangan delegasi bisa diatikan bahwa pemerintah melimpahkan kewenangan terkait pengaturan kawasan yang menjadi area 
terlarang bagi rokok kepada pemerintah daerah berdasarkan atas hukum positif untuk menerapkan kebijakan - kebijakan terhadap kawasan terlarang bagi rokok di wilayah yang menjadi kewenangannya. ${ }^{6}$ Wujud dari pelimpahan kewenangan tersebut pemerintah daerah menetapkan area - area dilarang merokok atau lingkungan tanpa asap rokok dengan menerbitkan peraturan daerah tentang Kawasan Tanpa Rokok. Berikut adalah contoh daerah dalam menerbitkan aturan daerah maupun peraturan kepala daerah terkait Kawasan Tanpa Rokok adalah Pemerintahan di Kabupaten Badung.

Pemerintahan daerah di Kabupaten Badung menerbitkan "Peraturan Daerah Nomor 8 Tahun 2013 Tentang Kawasan Tanpa Rokok" sebagaimana yang telah dirubah menjadi "Peraturan Daerah Kabupaten Badung Nomor 10 Tahun 2017 Tentang Perubahan Atas Peraturan Daerah Nomor 8 Tahun 2013 Tentang Kawasan Tanpa Rokok" (selanjutnya disebut Perda Badung Tentang KTR) sebagai instumen hukum dalam melaksakan kawasan tanpa rokok ( pada pembahasan berikutnya ditulis KTR) di Kabupaten Badung. Sebagai pelaksanaan dalam Perda Badung Tentang KTR ini Pemerintah Kabupaten Badung juga menerbitkan Peraturan Bupati Badung Nomor 71 Tahun 2014 Tentang Pelaksanaan Kawasan Tanpa Rokok (selanjutnya disebut dengan Perbub Badung Tentang Pelaksanaan KTR). Dalam ketentuan Perda Badung Tentang KTR dan Perbup Badung Tentang Pelaksanaan KTR menegaskan bahwa Kawasan Tanpa Rokok adalah sebuah kawasan atau lingkungan ataupun area yang tidak diijinkan untuk melakukan kegiatan - kegiatan yang berhubungan dengan aktivitas merokok ataupun kegiatan perdagangan rokok seperti aktivitas menjual serta mebeli rokok, dan melakukan kegiatan promosi produk rokok atau produk tembakau lainnya. Kegiatan - kegiatan tersebut sangat terlarang dilakukan pada area yang sudah ditetapkan sebagai KTR. Penetapan KTR sejalan pada kebijakan untuk memberikan perlindungan serta jaminan kesehatan bagi masyarakat yang tidak merokok atau perokok pasif. Dalam menjalakan kebijakan Kawasan Tanpa Rokok, Pemerintah Kabupaten Badung membuat pedoman pelaksanaan yang di tuangkan dalam Perbup Badung Tentang Pelaksanaan KTR.

Kebijakan Kawasan Tanpa Rokok ini dibentuk semata - mata untuk memenuhi kewajiban Pemerintah Daerah Kabupaten Badung untuk melindungan warga masyarakatnya dari bahaya rokok. Namun pada perkembangannya rokok pun pada saat ini memiliki perkembangan dan inovasinya yang kian hari bertumbuh dengan cepat sejalan dengan meningkatnya teknologi. Perkembangan rokok pun berubah dari arah rokok konvensional yang terbuat dari tembakau ke rokok modern yang disintesiskan

${ }^{6}$ Rokhim, A. "Kewenangan Pemerintahan Dalam Konteks Negara Kesejahteraan (Welfare State)". Jurnal Ilmiah Ilmu Hukum Dinamika Hukum, (2013). hlm. 136. 
menjadi cairan yang sering disebut dengan vape (rokok elektrik). Kegiatan merokokpun berubah dari dahulu orang menghisap rokok dari tembakau menjadi menghisap uap pembakaran dari vape (rokok elektrik). Perubahan pola prilaku masyarakat dari rokok konvensional menjadi rokok elektrik menyebabkan terjadinya kekaburan norma dalam penerapan kebijakan Kawasan Tanpa Rokok. Kekaburan norma ini terjadi karena vape (rokok elektrik) tidak diatur secara eksplisit dalam Perda Badung Tentang KTR maupun Perbup Badung Tentang Pelaksanaan KTR. Padahal pada kenyataannya vape (rokok elektrik) memiliki bahaya yang bukan hanya diterima oleh perokok aktif vape (rokok elektrik), tetapi oleh perokok pasif yang menghirup asap dari vape (rokok elektrik) tersebut. Bahaya yang di timbulkan oleh rokok elektrik sama seperti rokok konvensional, hal tersebut dikarenakan bahwasannya semua rokok memiliki kandungan yang sama berupa nikotin. Selain kandungan nikotin, ada berbagai zat-zat berbahaya di dalam rokok elektrik seperti diasetil, akrolein, asetaldehida, logam berat, formaldehida, propanal, yang hampir sama seperti kandungan rokok konvensional atau rokok dari olahan tembakau. ${ }^{7}$

Hal tersebut juga dikuatkan dari hasil penelitian American Public Health Association yang menjelaskan bahwa rokok elektrik dapat menyebabkan kanker, serangan jantung, gangguang saluran pernapasan, hipertensi serta kecanduan nikotin dalam darah. ${ }^{8}$ Berdasarkan pemaparan diatas dapat diketahui bahwasannya bahaya dari aktivitas merokok dengan vape (rokok elektrik) hampir sama dengan rokok konvensional. Dampak dari vape (rokok elektrik) bagi perokok pasif tidak jauh berbeda dengan dampak dari menghirup asap pembakaran tembakau orang merokok konvensional. Dampak penyakit atas timbulnya akibat paparan polutan pembakaran pada aktivitas merokok contohnya adalah hipertensi dan gangguan saluran pernapasan atas. Berdasarkan data BPS Kabupaten Badung terjadi peningkatan signifikan terhadap penderita hipertensi. Peningkatan hipertensi diperlihatkan dari data tahun 2017 jumlah penderita hipertensi sebesar 1.894, meningkat pada tahun 2018 menjadi 10.274. ${ }^{9}$ Data untuk penyakit gangguang saluran pernapasan atas juga mengalami peningkatan yang signignifikan yaitu

\footnotetext{
${ }^{7}$ Alodokter. Bahaya Vaping Tidak Jauh Beda Dengan Rokok Tradisional. Available from https://www.alodokter.com/bahaya-vaping-tidak-jauh-beda-dengan-bahaya-rokok-tradisional (Diakses 15 Oktober 2019)

${ }^{8}$ Voigt, K. Smoking norms and the regulation of e-cigarettes. American journal of public health, 105(10), (2015). 1967-1972.

9 Badan Pusat Statistik Kabupaten Badung, Badung Dalam Angka 2019, BPS Kabupaten Badung, Mangupura,2019, hlm.153.
} 
berdasarkan data BPS Kabupaten Badung tahun 2017 jumlah penderitanya 2.424, pada tahun berikutnya naik menjadi $6.727 .^{10}$

Berdasarkan data di atas penting bagi Pemerintah Kabupaten Badung menerapkan kebijakan Kawasan Tanpa Rokok sebagai upaya mencegah serta upaya penanggulangan penyakit - penyakit yang mengkin timbul dari kegiatan merokok. Larangan merekok pada kawasan tertentu memberikan perlindungan bagi masyarakat perokok pasif untuk hidup lebih sehat dan menciptakan area kawasan yang aman bagi kesehatan dan bersih dari polutan rokok untuk semua orang. Akan tetapi penerapan KTR terhadap orang merokok dengan rokok elektrik memiliki kekaburan norma dalam penerapannya. Karena masih ada perdebatan di masyarakat apakah rokok elektrik masuk kategori rokok dalam ruang lingkup Perda Badung Tentang KTR ataupun Perbup Badung Tentang Pelaksanaan KTR. Perdebatan tersebut menimbulkan ketidakpastian hukum bagi penyelenggaraan KTR di Kabupaten Badung. Belum dicantumkannya rokok elektrik pada aturan KTR di Kabupaten Badung menyebabkan penerapannya belum berjalan efektif untuk perokok yang merokok menggunakan rokok elektrik, walaupun di satu sisi rokok elektif berdasarkan beberapa kajian juga memiliki bahaya yang serupa dengan rokok konvensional. Karena pentingnya penerapan kebijakan Kawasan Tanpa Rokok ini sebagai sarana perlindungan hak - hak asasi masyarakat untuk mendapatkan area yang terjamin bersih dan aman untuk kesehatan serta mencegah dampak negatif dari rokok elektrik, mata atas pemaparan tersebut penulis menarik untuk mengkaji hal ini dan menjadikan kajian ini menjadi sebuah karya ilmiah hukum yaitu jurnal dengan judul kajian adalah "Kebijakan Kawasan Tanpa Rokok Terhadap Pengguna Vape (Rokok Elektrik) di Kabupaten Badung.

Tujuan inti atas keinginan penelitian dalam kajian tulisan karya penulis ini adalah diharapkan dapat menemukan titik temu dari perdebatan apakah perokok dengan vape (rokok elektrik) bisa masuk ruang lingkup dari Kawasan Tanpa Rokok itu, mengingat perlindungan kesehatan masyarakat sangat penting diwujudkan oleh Pemerintah Kabupaten Badung untuk melindungi Hak Asasi masyarakat yang menginginkan lingkungan yang sehat dan bebas paparan polutan dari asap bakar aktivitas merokok baik merokok konvensional maupun merokok dengan vape. Perlindungan kesehatan masyarakat adalah bagian usaha pada upaya dari pemerintah untuk menjamin hak - hak fundamental masyarakat untuk mendapatkan lingkungan aman terhadap kesehatan masyarakat sesuai amanat UUD NRI 1945. Tujuan lain adalah untuk memberikan informasi serta pengetahuan bagi masyarakat terhadap penggunaan vape (rokok elektrik) diterapkan dalam Kawasan Tanpa Rokok 
serta informasi terkait kebijakan Pemerintah Kabupaten Badung dalam Kawasan Tanpa Rokok.

Pada hakekatnya bahwa kebijakan terkait Kawasan Tanpa Rokok yang dilaksanakan oleh pemerintah daerah sangat penting disebarluaskan kepada masyarakat agar dapat ditaati oleh masyarakat. Begitu pula hambatan hambatan dalam penerapannya perlu dilakukan sosialisasi terhadap masyarakat luas terhadap kebijakan Kawasan Tanpa Rokok dan kajian - kajian terkait perkembangan dinamika yang terjadi di masyarakat. Gambaran diatas setidaknya diungkapkan oleh hasil kajian maupun penelitian hukum yang ditulis oleh Santosa pada tahun 2016. ${ }^{11}$

Keberhasilan kebijakan Kawasan Tanpa Rokok tidak hanya kurangnya penyebarluasan informasi, tapi perlunya kesadaran masyarakat untuk mematuhinya dan memiliki kesadaran hukum untuk tidak merugikan masyarakat lain dengan tidak menghidupakan rokok di KTR. Keberhasilan juga ditunjang dengan memperbanyak tanda dilarangan menggunakan rokok pada KTR untuk memberitahukan bahwa area yang dimasuki adalah area dilarang merokok. Hasil penelitian itu juga di ungkapkan oleh Yana Agus Setianingsih pada penelitian tahun $2018 .^{12}$

\section{Permasalahan}

Dari judul kajian karya ilmiah di atas dapat ditarik rumusan masalah pada kajian yang akan di teliti sebagaimana berikut yaitu bagaimana kajian norma vape (rokok elektrik) masuk kedalam dalam Kawasan Tanpa Rokok ?, dan kewenangan Pemerintah Kabupaten Badung terhadap vape (rokok elektrik) pada Kawasan Tanpa Rokok ?

\section{Metode Penelitian}

Pengkajian penulisan dalam studi kajian hukum ini mempergunakan penelitian dengan metode hukum normatif. Pengkajian dengan studi hukum normatif ini pada kajian ini didasarkan atas ketidakpastian norma dalam kebijakan Kawasan Tanpa Rokok. ${ }^{13}$ Pendekatan dalam kajian studi hukum yang digunakan melalui pendekatan secara conceptual approach dan statute approach. Dalam pencarian terhadap bahan - bahan hukum pada kajian

${ }^{11}$ Santosa, S. H. “Kebijakan Pemerintah Daerah Tentang Kawasan Tanpa Rokok Dalam Peningkatan Kesehatan Masyarakat". Jurnal Hukum Dan Dinamika Masyarakat, 10 (2), (2016). $177-187$.

${ }^{12}$ Setianingsih, Y. A., Yustina, E. W., \& Widyorini, E. “Pelaksanaan Kebijakan Kawasan Tanpa Rokok (KTR) Sebagai Bagian Dari Perilaku Hidup Bersih Dan Sehat (PHBS) Di Lingkungan Pendidikan (Studi Kasus Pada STIKES Di Kota Semarang)". SOEPRA, 1(1) (2018), 106-114.

${ }^{13}$ Diantha, I. M. P., Metodologi Penelitian Hukum Normatif dalam Justifikasi Teori Hukum, Prenada Media, Jakarta, 2016, hlm. 12. 
penulisan artikel ini dipergunakan cara studi dokumen dengan teknik analisis dalam pengkajian penulisan artikel jurnal ini menggunakan cara analisis kualitatif untuk memperoleh bahasan yang konfrehensif dan kredibel dalam analisisnya.

\section{Pembahasan}

Bagaimana Kajian Norma Vape (Rokok Elektrik) Masuk Kedalam Dalam Kawasan Tanpa Rokok

Indonesia adalah negara yang dilandasi oleh norma tertulis sejalan dengan aturan dalam Pasal 1 UUD Indonesia 1945 pada ketentuan ayat ketiga. Atas dasar hal itu secara teori hukum bahwa segala sesuatu wajib berdasarkan atas hukum. Dengan kata lain setiap perbuatan harus terlebih dulu diatur dalam aturan atau norma hukum. Pernyataan itu sejalan dengan kosekuensi Indonesia menganut sistem negara hukum civil law system dengan persyaratan supremacy before the law. Persyaratan tersebut mensyaratkan Negara Indonesia memberikan kedudukan tinggi terhadap hukum dan memiliki kuasa penuh dalam mengatur negara dan warga negara. ${ }^{14}$ Akibat dari syarat tersebut dalam membuat kebijakan ataupun melarang suatu perbuatan harus didasarkan atas peraturan dalam tingkatan perundang - undangan positif. Berdasarkan landasan pikir itu seluruh kebijakan pemerintah harus didasarkan aturan hukum yang berlaku. Landasan pemikiran tersebut merupakan syarat agar suatu kebijakan dapat dilaksanakan. Aturan hukum menjadi pegangan serta dasar pemerintah dalam melakukan kebijakan maupun kewenangannya.

Perda Badung Tentang Kawasan Tanpa Rokok menjadi acuan maupun landasan Pemerintah Kabupaten Badung untuk mengatur Kawasan Tanpa Rokok. Dalam pelaksanaannya digunakan Perbup Badung Tentang Pelaksanaan Kawasan Tanpa Rokok. Aturan tersebut menjadi pijakan pemerintah untuk mengatur kegiatan merokok masyarakat agar tidak merugikan masyarakat. Dalam Perda Badung Tentang KTR diatur bahwa KTR adalah suatu area amaupun lingkungan dalam hal ini bebas dari aktivitas rokok, aktivitas promosi rokok maupun aktivitas jual beli rokok. Maksud dari bebas dari aktivitas merokok berarti di lokasi tersebut masyarakat dilarang untuk merokok. Merokok itu sendiri adalah aktivitas menghisap asap dari pembakaran rokok. Aktivitas tersebut dilarang di Kawasan Tanpa Rokok karena bukan hanya menimbulkan dampak bagi perokok, tapi menimbulkan dampak bagi perokok pasif. Dampak dari asap rokok itu sendiri sangat banyak

${ }^{14}$ Ridwan,H.R., Hukum Administrasi Negara, Edisi Revisi, Raja Grafindo Prasada, Jakarta 2014, hlm.18. 
seperti hipertensi, kanker maupun gangguan saluran pernapasan atas. ${ }^{15}$ Maka kebijakan Kawasan Tanpa Rokok dibuat untuk melindungi kesehatan maupun kepentingan perokok pasif serta kepentingan semua pihak dari bahaya aktivitas merokok.

Secara konseptual rokok dapat di terjemahkan sebagai salah satu bagian dari hasil olahan tembakau yang penggunaannya dibakar lalu asap pembakarannya dihisap. Rokok juga dikonsepkan sebagai olahan dari bahan bahan alam dari tumbuhan nicotiana rustica, nicotiana tabacum maupun spesies lainnya yang terkandung nikotin serta tar termasuk di dalamnya adalah sintesis atau ekstraksinya yang memiliki kandungan nikotin dan tar ataupun dengan tambahan maupun tidak berisi bahan tambahan lainnya. Secara normatif konsep rokok tersebut diatur dalam "Peraturan Pemerintah Republik Indonesia Nomor 109 Tahun 2012 Tentang Pengamanan Bahan Yang Mengandung Zat Adiktif Berupa Rokok Tembakau Bagi Kesehatan" (pada bahasan berikut ditulias PP Pengamanan Zat Adiktif). Pemahaman rokok dalam PP Pengamanan Zat Adiktif memiliki kesamaan dan kesatuan konsep dengan ruang lingkup rokok dalam Perda Badung Tentang Kawasan Tanpa Rokok. Jika kaji secara gramatikal ruang lingkup rokok bisa di interprestasikan sebagai vape (rokok elektrik).

Rokok elektrik secara gramatikal masuk kedalam ruang lingkup rokok karena dari segi pemakaian sama - sama di hisap, perbedaannya adalah cara pembakaran dan yang dibakar. Jika rokok konvensional yang dibakar adalah tembakau, maka rokok elektrik yang dibakar adalah liquid. Liquid dari vape itu sendiri merupakan ekstraksi nikotin dengan bahan tambahan propilen glikol, flavour yang menjadi senyawa air. ${ }^{16}$ Berdasarkan komposisi liquid dapat di analisis bahwa liquid merupakan sintesis dari nikotin. Nikotin itu sendiri merupakan didapatkan dari ekstrak daun tembakau yang di proses sedemikian rupa hingga menghasilkan cairan ataupun senyawa nikotin. ${ }^{17}$ Secara penamaan vape di beri nama lain berupa rokok elektrik. Penamaan vape itu berasal dari istilah e-cigarette yang dalam bahasa Indonesia berarti rokok. Penamaan cigarette pada vape dikarenakan vape itu sama - sama di hisap dan proses untuk memperoleh asap sama - sama melalui proses pembakaran. Perbedaannya jika rokok konvensional di bakar secara konvensional

15 Putra, I. G. N. I. S., \& Purwanto, I. W. N. “Perlindungan Hukum Terhadap Konsumen Terkait Tidak Adanya Tanggal Kadaluwarsa Dikemasan Rokok”. Kertha Semaya: Journal Ilmu Hukum, 7(6), (2019), hlm. 1-15.

${ }^{16}$ Fahamsyah, E. "Perlindungan Konsumen Terhadap Peredaran, Penggunaan, Dan Penggunaan E-Liquid Di Dalam Rokok Elektrik”. Jurnal Hukum Adigama, (2018). HIm. 1(1).

17 Listiyati, A. K., Nurkalis, U., \& Hestiningsih, R. "Ekstraksi Nikotin Dari Daun Tembakau (Nicotina Tabacum) Dan Pemanfaatannya Sebagai Insektisida Nabati Pembunuh Aedes Sp". Jurnal Ilmiah Mahasiswa, (2012). HIm. 2(2). 
menggunakan api, sedangkan vape proses pembakarannya melalui proses elektrikal. Atas dasar hal tesebut vape sebut dengan e-cigarette. ${ }^{18}$ Kesimpulannya adalah secara konseptual berdasarkan analisis gramatikal dari pengertian rokok dalam berdasarkan PP 109 Tahun 2012 Tentang Pengamana Zat Adiktif serta Perda Badung Terhadap Kawasan Tanpa Rokok, bahwa vape merupakan salah dari ruang lingkup pengertian rokok secara normatif.

Jika ditinjau dalam interprestasi histori, kebijakan untuk mengatur Kawasan Tanpa Rokok berangkat dari keinginan Pemerintah melindungi perokok pasif terhadap dampak kesehatan polutan asap orang merokok. Keinginan untuk melindungi orang yang pasif merokok dituangkan kedalam Perda Badung Tentang Kawasan Tanpa Rokok. Pada penjelasan pada bab 1 umum termaktub perihal urgensinya Pemerintah Kabupaten Badung mengatur hal tesebut. Salah satu penekanannya adalah pada bahaya paparan asap rokok. Interprestasi historis itu sendiri dimaknai sebagai penafsiran dengan cara melihat latar belakang ketentuan peraturan perundang - undangan itu dibuat. ${ }^{19}$ Atas pengertian tersebut, bahwa Perda Badung Tentang KTR ingin memproteksi orang - orang di Kabupaten Badung atas bahaya paparan polutan orang merokok. Sejalan dengan hal itu PP 109 Tahun 2012 Tentang Pengamana Zat Adiktif juga di buat didasari atas keresahan pemerintah akan bahaya rokok bagi kesehatan masyarakat sekaligus sebagai pelaksanaan terhadap pengamanan zat adiktif yang beredar di masyakatat.

Secara historis kedua kebijakan tersebut memiliki satu tujuan yaitu ingin menciptakan masyarakat sehat dan area lingkungan bebas polutan orang merokok. atas dasar historis tersebut rokok konvensional maupun rokok elektrik sama - sama memiliki bahaya bagi kesehatan masyarakat. Rokok konvensional dan rokok elektrik dalam penggunaanya sama - sama mengeluarkan asap yang memiliki kandungan bahaya yang serupa. Maka ditinjau dari interprestasi historis bahwa rokok elektrik secara harpiah merupakan rokok yang di interprestasikan suatu kegiatan atau aktivitas memiliki dampak negatif bagi masyarakat. ${ }^{20}$ Interprestasi itu memiliki kerangka pemikiran dari latar belakang pembentukan ataupun latar belakang historis Perda Badung Tentang Kawasan Tanpa Rokok yang ingin melindungi perokok pasif dari bahaya zat adiktif. Zat adiktif yang dimaksud adalah nikotin yang berasal dari sintesis tembakau.

${ }^{18}$ Zimlich, C. M. "What Is a Cigarette-Electronic Cigarettes and the Tobacco Master Settlement Agreement". Wake Forest L. Rev., 50, (2015). HIm. 483.

${ }_{19}$ Peter, M.M., Penelitian Hukum Edisi Revisi. Cetakan ke-8, Kencana Prenada Media Group, Jakarta, 2013, hlm.152

${ }^{20}$ Leventhal, A. M., Stone, M. D., Andrabi, N., Barrington-Trimis, J., Strong, D. R., Sussman, S., \& Audrain-McGovern, J. "Association of e-cigarette vaping and progression to heavier patterns of cigarette smoking”. Jama, 316(18), (2016) 1918-1920.) 
Vape (rokok elektrik) jika dikaji menggunakan aturan dari tingkatan perundang - undangan positif bisa dikatakan sebagai salah satu turunan produk tembakau. Analisis atas dasar pikiran dari "Undang - Undang Republik Indonesia Nomor 39 Tahun 2007 Tentang Perubahan Atas Undang - Undang Nomor 11 Tahun 1995 Tentang Cukai" (selanjutnya disebut dengan UU Cukai) yang pada dasarnya pengenaan cukai dikenakan kepada barang atau produk tertentu yang memiliki karakter yang dimana dalam mengkonsumsinya perlu diawasi serta memiliki dampak negatif. Dalam Undang - Undang Cukai salah satu komponen yang dikenai cukai adalah produk tembakau. Produk - produk yang dihasilkan oleh pengelohan tembakau bisa dikatakan berbagai macam produk, salah satu produk tersebut adalah rokok. Turunan dari Undang Undang Cukai ini adalah diterbitkannya "Peraturan Menteri Keuangan Republik Indonesia Nomor 152 /PMK.010/2019 Tentang Perubahan Kedua Atas Peraturan Menteri Keuangan Nomor 146/PMK.010/2017 Tentang Tarif Cukai Hasil Tembakau" (selanjutnya disebut dengan PMK Tentang Cukai Tembakau) yang mengatur pengenaan tarif dari berbagai hasil olahan tembakau. Berdasarkan PMK Tentang Cukai Tembakau rokok elektrik dikategorikan sebagai salah satu produk tembakau yang merupakan Hasil Pengolahan Tembakau Lainnya (HPTL). Pernyataan itu diperkuat oleh pendapat Kementerian Keuangan bahwa rokok elektrik dikenakan cukai tembakau. ${ }^{21}$ Atas analisis tersebut rokok elektronik dikatakan sebagai salah satu hasil produk tembakai lainnya. Analisis tersebut sejalan dengan ruang ringkup rokok dalam Perda Badung Tentang KTR. Maka dari analis konsep dan analisis perundang - undangan dapat ditemukan kesimpulan rokok elektrik merupakan hasil olahan tembakau lainnya yang dapat dipersamakan dengan rokok.

Berdasarkan atas analisa dan pemaparan di atas rokok elektrik masuk dalam cakupan pemahaman dan ruang lingkup rokok dalam Perda Badung Tentang Kawasan Tanpa Rokok . Kegiatan menghisap rokok elektrik dapat dipersamakan dengan merokok dengan media vape (rokok elektrik) sebagai objek perbuatannya. Jika ditinjau pengertian dan pemahanan terhadap Kawasan Tanpa Rokok, berdasarkan Perda Badung Tentang Kawasan Tanpa Rokok merupakan sebuah area ataupun lingkungan dilarang untuk merokok, atau melakukan segala aktivitas yang berkaitan dengan rokok maupun produk tembakau baik dalam rangka untuk menggunakannya, menjual serta membeli, dan melakukan pemasaran terhadap produk tersebut. Dari pemahaman tersebut bahwa pengguna rokok elektrik dilarang melakukan aktivitas merokok dalam Kawasan Tanpa Rokok. Larangan merokok diatur secara jelas pada

${ }^{21}$ Merdeka. Tidak Hanya Rokok, Cukai Rokok Elektrik Juga Naik Pada Tahun 2020. Available from https://www.merdeka.com/uang/tak-hanya-rokok-cukai-rokok-elektrik-jugabakal-naik-di-januari-2020.html (Diakses 14 November 2019). 
Pasal 15 ayat (1) Perda Badung Tentang KTR. Maka diambil simpulan bahwa pada KTR dilarang untuk menggunakan vape (rokok elektrik). Kesimpulan tersebut juga menggambarkan pengaturan vape (rokok elektrik) secara eksplisit di atur dalam ketentuan Perda Badung Tentang Kawasan Tanpa Rokok. Pengaturan tersebut tergambarkan pada ruang lingkup rokok yang termaktub dalam Pasal 1 angka 7 Perda Badung Tentang Kawasan Tanpa Rokok.

\section{Kewenangan Pemerintah Kabupaten Badung Terhadap Vape (Rokok Elektrik) Pada Kawasan Tanpa Rokok}

Kewenangan memiliki makna kata berupa kekuasan atau hak dalam menjalankan kuasa untuk membuat kebijakan sendiri maupun memberikan kuasa kepada orang lain untuk bertanggung jawab atas sesuatu. Sumber dari kewenangan pemerintah berasal dari berbagai sumber dan dirincikan menjadi tiga yaitu kewenangan atribusi, wewenang delegasi dan kuasa mandat. Kewenangan asal mula dari undang - undang adalah bentuk wewenang atribusi, sedangkan kewenangan delegasi merupakan pemimpahan kuasa berwenang oleh pemerintah kepada pemerintahan lainnya untuk melaksanakan kuasa atas wewenang tersebut. Sedangkan mandat di istilahkan sebagai wewenang untuk mewakili atasan yang diberikan oleh bawahan. ${ }^{22}$ Kewenangan adalah dasar landasan bertindak dalam melakukan tindakan hukum ataupun melakukan kebijakan hukum yang dilakukan pemerintah. Pemberian kewenangan untuk membuat kebijakan wajib berlandaskan pada norma perundang - undangan positif. Norma tertulis perundang - undangan menjadi landasan serta pedoman pemerintah dalam membuat kebijakan. Secara teori bahwa dalam melakukan setiap tindakan hukum publik, pemerintah wajib untuk memiliki kewenangan atas hal tersebut. ${ }^{23}$

Dalam membuat kebijakan, pemerintahan daerah diberi wewenang dari pemerintah melalui otonomi daerah dalam membuat kebijakan yang mengatur masyarakat di daerah. Ketentuan tersebut termaktub di "Undang - Undang Republik Indonesia Nomor 23 Tahun 2014 Tentang Pemerintahan Daerah" (pada bahasan berikutnya ditulis UU Pemda). Dalam UU Pemda tersebut pemerintah telah membagi urusan antara pemerintah dengan pemerintahan di daerah. Contoh pembagian tersebut pada urusan kaitannya bidang kesehatan. Urusan kesehatan salah satu bidang yang menjadi tanggung jawab bersama.

${ }^{22}$ Suharizal, Muslim., C., Hukum Pemerintah Daerah Setelah Perubahan UUD 1945, Thafa Media, Jakarta, 2017, hlm. 22.

23 Artaya, A. "Kewenangan Pemerintah Kabupaten Badung Dalam Pengendalian Perizinan Pembangunan Sarana Akomodasi Pariwisata". Jurnal Magister Hukum Udayana (Udayana Master Law Journal), 5(3), (2016). Hlm. 543-558. 
Salah satu contoh kewenangan atas urusan kesehatan adalah kebijakan KTR. Kebijakan merupakan delegasi kewenangan berdasarkan "Undang - Undang Republik Indonesia Nomor 36 Tahun 2009 Tentang Kesehatan" (pada bahasan berikutnya ditulis UU Kesehatan). Ketentuan pada Pasal 115 di ayat kedua mewajibkan pemerintah daerah untuk merumuskan dan mengatur norma positif terhadap KTR. ${ }^{24}$

Pengaturan KTR di Kabupaten Badung termaktib pada Perda Badung Tentang KTR. Pengaturan KTR mengatur terkait pelarangan rokok di area yang telah di tetapkan dalam Perbup Badung Tentang Pelaksanaan Kawasan Tanpa Rokok. Selain kegiatan merokok, dalam KTR juga melarang untuk melakukan aktivitas perdagangan produk rokok serta melakukan publikasi atau mempromosikan olahan tembakau termasuk rokok dan sintesisnya. Berdasarkan pembahasan sebelumnya bahwa rokok elektrik masuk pada definisi rokok. Sedangkan kegiatan merokok adalah kegiatan untuk membakar serta menghirup asap pembakaran dari rokok itu sendiri. Jadi secara harpiah dapat di terjemahkan bahwa pengguna vape (rokok elektrik) pelarangan merokok di KTR yang telah ditetapkan.

Kewenangan Pemerintah Kabupaten Badung terhadap pengguna vape (rokok elektrik) adalah melarang penggunaannya di area yang masuk pada Kawasan Tanpa Rokok. Larangan itu juga berlaku untuk kegiatan jual beli vape (rokok elektrik) di area lingkungan yang telah di tetapkan sebagai Kawasan Tanpa Rokok. Pemerintah dengan kewenangan wajib bertindak jika terjadi pelanggaran Kawasan Tanpa Rokok oleh pengguna vape (rokok elektronik). Tindakan preventif yang bisa dilakukan pemerintah Kabupaten Badung adalah dengan memberikan sosialisasi kepada masyarakat bahwa pada dasarnya penggunan vape (rokok elektrik) di Kawasan Tanpa Rokok dilarang. Selain itu pemerintah Kabupaten Badung dapat melakukan upaya pemasangan penanda tambahan pada Kawasan Tanpa Rokok bahwa vape (rokok elektrik) masuk kategori melanggar Perda Badung Tentang Kawasan Tanpa Rokok. Langkah represif yang bisa diambil berdasarkan kewenangan yang di berikan pada Perda Badung Tentang Kawasan Tanpa Rokok adalah melakukan penegakan hukum bagi pengguna rokok pada khususnya pengguna rokok elektrik yang kedapatan merokok pada Kawasan Tanpa Rokok.

Berdasarkan pemaparan diatas bahwa kewenangan pemerintah Kabupaten Badung terhadap penggunaan rokok elektrik pada Kawasan Tanpa Rokok didasarkan atas Perda Badung Tentang Kawasan Tanpa Rokok. Dalam ketentuan tersebut pemerintah diberikan kewenangan untuk melakukan

${ }^{24}$ Ernawati, A. "Implementasi Kebijakan Kawasan tanpa Rokok di RSUD Raa Soewondo Pati”. Jurnal Litbang: Media Informasi Penelitian, Pengembangan dan IPTEK, 12(2) (2016), 136-147. 
tindakan prefentif maupun represif. Tindakan preventif dilakukan oleh badan atau organ pemerintah Kabupaten Badung yang menyelenggaraan kesehatan. Tindakan preventif tersebut adalah dengan cara monitoring, sosialisasi, dan evalusasi terhadap penggunaanr rokok elektrik di Kawasan Tanpa Rokok. Tindakan represif yang bisa dilakukan pemerintah Kabupaten Badung adalah melakukan pendegakan hukum melalui organ Pemerintah Kabupaten Badung yang membidangan masalah pelanggaran peratruran daerah. Tindakan refresif yang dilakukan oleh Pemerintah Kabupaten Badung adalah demgam penetapan denda terhadap pelanggarnya maupun kurungan pidana pelanggaran peraturan daerah.

\section{Penutup}

\section{Simpulan}

Pengaturan terhadap vape (rokok elektrik) terhadap Kawasan Tanpa Rokok pada dasarnya sama dengan pengaturan rokok. Kajian Tersebut di dapat dari interprestasi pengertian rokok yang ada pada ketentuan Perda Badung Terhadap Kawasan Tanpa Rokok. Persamaan itu di gambarkan dari ruang lingkup rokok Perda Badung Terhadap Kawasan Tanpa Rokok. Berdasarkan ruang lingkup vape (rokok elektrik) itu, maka pengaturan pelarangan vape (rokok elektrik) pada Kawasan Tanpa Rokok sama dengan pengaturan rokok konvensional pada Kawasan Tanpa Rokok.

\section{Saran}

Atas dasar ruang lingkup vape (rokok elektrik) yang merupakan bagian dari pengertian rokok, maka kewenangan pemerintah terhadap pengguna vape (rokok elektrik) pada Kawasan Tanpa Rokok adalah pelarangan untuk penggunaannya. Pemerintah Kabupaten Badung memiliki kewenangan untuk melakukan tindakan hukum terkait penggunaan vape (rokok elektrik) Kawasan Tanpa Rokok. Kewenangan tersebut di dasarkan atas Perda Badung Tentang Kawasan Tanpa Rokok. Kewenangan tindakan hukum yang bisa dilakukan oleh Pemerintah Kabupaten Badung adalah sosialiasasi sebagai lahkan preventif. Langkah Represif dapat dikakukan dengan mengenai denda atau pidana pelanggaran terhadap pengguna vape (rokok elektrik) pada Kawasan Tanpa Rokok. 


\section{Daftar Pustaka}

Buku

Agus Salim Andi Gadjong, Pemerintah Daerah Kajian Politik dan Hukum, Ghalia Indonesia, Bogor, 2007.

Badan Pusat Statistik Kabupaten Badung, Badung Dalam Angka 2019, BPS Kabupaten Badung, Mangupura, 2019.

Diantha, I. M. P., Metodologi Penelitian Hukum Normatif dalam Justifikasi Teori Hukum, Prenada Media, Jakarta, 2016.

Peter, M.M., Penelitian Hukum Edisi Revisi. Cetakan ke-8, Kencana Prenada Media Group, Jakarta, 2013.

Ridwan,H.R., Hukum Administrasi Negara, Edisi Revisi, Raja Grafindo Prasada, Jakarta 2014.

Suharizal, Muslim., C., Hukum Pemerintah Daerah Setelah Perubahan UUD 1945, Thafa Media, Jakarta, 2017.

Jurnal

Artaya, A. "Kewenangan Pemerintah Kabupaten Badung Dalam Pengendalian Perizinan Pembangunan Sarana Akomodasi Pariwisata”. Jurnal Magister Hukum Udayana (Udayana Master Law Journal), 5(3), 543-558. (2016).

Aswandi, B., \& Roisah, K. "NEGARA HUKUM DAN DEMOKRASI PANCASILA DALAM KAITANNYA DENGAN HAK ASASI MANUSIA (HAM)". Jurnal Pembangunan Hukum Indonesia, 1(1), 128-145. (2019).

Ernawati, A. “Implementasi Kebijakan Kawasan tanpa Rokok di RSUD Raa Soewondo Pati". Jurnal Litbang: Media Informasi Penelitian, Pengembangan dan IPTEK, 12(2), 136-147. (2016).

Fahamsyah, E. "PERLINDUNGAN KONSUMEN TERHADAP PEREDARAN, PENGGUNAAN, DAN PENGGUNAAN E-LIQUID DI DALAM ROKOK ELEKTRIK”. Jurnal Hukum Adigama, 1(1). (2018).

Leventhal, A. M., Stone, M. D., Andrabi, N., Barrington-Trimis, J., Strong, D. R., Sussman, S., \& Audrain-McGovern, J. "Association of e-cigarette vaping and progression to heavier patterns of cigarette smoking”. Jama, 316(18), 1918-1920. (2016).

Listiyati, A. K., Nurkalis, U., \& Hestiningsih, R. “Ekstraksi Nikotin Dari Daun Tembakau (Nicotina Tabacum) Dan Pemanfaatannya Sebagai Insektisida Nabati Pembunuh Aedes Sp”. Jurnal Ilmiah Mahasiswa, 2(2). (2012).

Prabhta, I. G. A. N. I. "Meningkatkan Pariwisata Bali melalui Kepastian Penegakan Hukum Atas Pelanggaran Kawasan tanpa Rokok dalam Peraturan Daerah Propinsi Bali Nomor 10 Tahun 2011”. Jurnal Magister Hukum Udayana (Udayana Master Law Journal), 4(1). (2015). 
Putra, I. G. N. I. S., \& Purwanto, I. W. N. “PERLINDUNGAN HUKUM TERHADAP KONSUMEN TERKAIT TIDAK ADANYA TANGGAL KADALUWARSA DIKEMASAN ROKOK". Kertha Semaya: Journal Ilmu Hukum, 7(6), 1-15. (2019)

Rokhim, A. "Kewenangan Pemerintahan Dalam Konteks Negara Kesejahteraan (Welfare State)". Jurnal Ilmiah Ilmu Hukum Dinamika Hukum, 136. (2013).

Santosa, S. H. "KEBIJAKAN PEMERINTAH DAERAH TENTANG KAWASAN TANPA ROKOK DALAM PENINGKATAN KESEHATAN MASYARAKAT”. Jurnal Hukum Dan Dinamika Masyarakat, 10 (2), 177 - 187. (2016).

Setianingsih, Y. A., Yustina, E. W., \& Widyorini, E. “Pelaksanaan Kebijakan Kawasan Tanpa Rokok (KTR) Sebagai Bagian Dari Perilaku Hidup Bersih Dan Sehat (PHBS) Di Lingkungan Pendidikan (Studi Kasus Pada STIKES Di Kota Semarang)". SOEPRA, 1(1), 106-114. (2018).

Shirley, K. F. L., \& Siarif, T. J. “KEBIJAKAN TENTANG PEDOMAN KAWASAN TANPA ROKOK DIKAITKAN DENGAN ASAS MANFAAT”. SOEPRA, 2(1), 104111. (2016).

Voigt, K. Smoking norms and the regulation of e-cigarettes. American journal of public health, 105(10), 1967-1972. (2015).

Zimlich, C. M. "What Is a Cigarette-Electronic Cigarettes and the Tobacco Master Settlement Agreement”. Wake Forest L. Rev., 50, 483. (2015).

Internet

“Bahaya Menjadi Perokok Pasif”, https://www.alodokter.com/bahayamenjadi-perokok-pasif, Diakses tanggal 10 Oktober 2019.

"Bahaya Vaping Tidak Jauh Beda Dengan Rokok Tradisional", https: / /www.alodokter.com/bahaya-vaping-tidak-jauh-beda-denganbahaya-rokok-tradisional, Diakses tanggal 15 Oktober 2019.

“Tidak Hanya Rokok, Cukai Rokok Elektrik Juga Naik Pada Tahun 2020”, https: / / www.merdeka.com/uang/tak-hanya-rokok-cukai-rokokelektrik-juga-bakal-naik-di-januari-2020.html, Diakses tanggal 14 November 2019.

\section{Peraturan Perundang-Undangan}

Undang-Undang Dasar Negara Republik Indonesia Tahun 1945

Undang - Undang Republik Indonesia Nomor 11 Tahun 1995 Tentang Cukai, Lembaran Negara Republik Indonesia Tahun 1995 Nomor 76, Tambahan Lembaran Negara Republik Indonesia Nomor 3615.

Undang - Undang Republik Indonesia Nomor 39 Tahun 2007 Tentang Perubahan Atas Undang - Undang Nomor 11 Tahun 1995 Tentang Cukai, Lembaran 
Negara Republik Indonesia Tahun 2007 Nomor 105, Tambahan Lembaran Negara Republik Indonesia Nomor 4755

Undang - Undang Republik Nomor 36 Tahun 2009 Tentang Kesehatan, Lembaran Negara Republik Indonesia Tahun 2009 Nomor 144, Tambahan Lembaran Negara Republik Indonesia Nomor 5587.

Peraturan Pemerintah Republik Indonesia Nomor 109 Tahun 2012 Tentang Pengamanan Bahan Yang Mengandung Zat Adiktif Berupa Rokok Tembakau Bagi Kesehatan, Lembaran Negara Republik Indonesia Tahun 2012 Nomor 278, Tambahan Lembaran Negara Republik Indonesia Nomor 5380.

Peraturan Menteri Keuangan Republik Indonesia Nomor 152 /PMK.010/2019 Tentang Perubahan Kedua Atas Peraturan Menteri Keuangan Nomor 146/PMK.010/2017 Tentang Tarif Cukai Hasil Tembakau, Berita Negara Republik Indonesia Tahun 2019 Nomor 1251.

Pemerintah Kabupaten Badung menerbitkan Peraturan Daerah Nomor 8 Tahun 2013 Tentang Kawasan Tanpa Rokok, Lembaran Daerah Kabupaten Badung Tahun 2013 Nomor 8, Tambahan Lembaran Daerah Kabupaten Badung Nomor 8.

Peraturan Daerah Kabupaten Badung Nomor 10 Tahun 2017 Tentang

Perubahan Atas Peraturan Daerah Nomor 8 Tahun 2013 Tentang Kawasan Tanpa Rokok,Lembaran Daerah Kabupaten Badung Tahun 2017 Nomor 10, Tambahan Lembaran Daerah Kabupaten Badung Nomor 10.

Peraturan Bupati Badung Nomor 71 Tahun 2014 Tentang Pelaksanaan Kawasan Tanpa Rokok, Lembaran Daerah Kabupaten Badung Tahun 2014 Nomor 71. 